\title{
FRAMING US-MEXICAN BORDERLANDS: PHILLIP RODRIGUEZ' VISUAL AESTHETICS
}

\author{
Inge Lanslots ${ }^{1}$ \\ Natalie Dupré 1 \\ ${ }^{1}$ Katholieke Universiteit Leuven, Leuven, Flandres, Belgium
}

\begin{abstract}
The US-Mexican border towns are often defined as both multicultural and relatively young transnational cities, which have grown apart despite their common historical past. The border policy, which actually started during Eisenhower's administration, seems to favor further differences. Border towns as well as the identity (construction) of their inhabitants - whether they are in passing or not - now seem to change more drastically. The present article analyzes how documentary film-maker Phillip Rodriguez translates urban imagery and ethnographic shifts to the screen, in particular in Mixed Feelings: San Diego/Tijuana (2002) and Los Angeles Now (2003). Close attention will be paid to multimodal strategies and other discursive practices, as well as to the dominant use of English language and the somehow biased focus on the social actors involved in the border zone. We argue that, in his portrayal of border towns, Rodriguez invites his audience to consider border towns from a mainly northern perspective, aiming to represent multilayered and connected worlds, while visualizing dual and divided spaces. We thus seek to answer the question to which extent this discourse on border towns enriches the larger socio-cultural polysystem in terms of transmission of knowledge and affects related to living experiences in urban borderlands. Keywords: Border; Phillip Rodriguez; Film Documentary; Urban Imagery; Monolingualism
\end{abstract}




\title{
ENQUADRANDO AS FRONTEIRAS DOS ESTADOS UNIDOS E MÉXICO: A ESTÉTICA VISUAL DE PHILLIP RODRIGUEZ
}

\begin{abstract}
Resumo: As cidades fronteiriças dos Estados Unidos e do México são geralmente definidas como multiculturais e cidades transnacionais relativamente recentes, as quais se afastaram apesar de seu passado histórico comum. A política de fronteira, que começou efetivamente durante a administração de Eisenhower, parece favorecer outras diferenças. Cidades fronteiriças, assim como a (construção) da identidade de seus habitantes - estejam eles de passagem ou não - agora parecem mudar mais drasticamente. O presente artigo analisa como o documentarista Phillip Rodriguez traduz o imaginário urbano e as mudanças etnográficas para as telas, especialmente em Mixed Feelings: San Diego/Tijuana (2002) e Los Angeles Now (2003). Será dada muita atenção às estratégias multimodais e outras práticas discursivas, assim como para o dominante uso da Língua Inglesa e ao enfoque de alguma forma enviesado dos atores sociais envolvidos na zona de fronteira. Nós argumentamos que, em seu retrato das cidades fronteiriças, Rodriguez convida sua audiência a considerar essas cidades a partir de uma perspectiva do norte, desejando representar mundos multifacetados e conectados, enquanto se visualiza espaços duais e divididos. Procuramos, dessa forma, responder a questão de em que medida o discurso nas cidades fronteiriças enriquece o polissistema socio-cultural em termos de transmissão de conhecimento e dos efeitos relacionados às experiências de vida em fronteiras urbanas.
\end{abstract}

Palavras-chave: Fronteira; Phillip Rodriguez; Documentário; Imaginário Urbano; Monolinguismo

\section{Re-bordering}

US-Mexican border towns are often defined as both multicultural and relatively young transnational cities, which despite their common historical past - have grown apart because of their administration, as Lawrence Herzog and Christophe Sohn rightfully point out: 
The evolution of transfrontier metropolitan regions remains a very recent phenomenon if one looks at the historical relationship between cities and territorial boundaries. Toward the end of last century, border territory was no longer considered as a buffer zone, but had transformed into an urban configuration at "the interplay between the flows of globalization' ("The Cross-Border Metropolis” 242).

These transformation processes were already defined as "a zone of confluence" (Lynch and Appleyard) in the 1970s. In the aftermath of $9 / 11$, this de-bordering process came to an end, changing the US-Mexican border from an economic resource to an obstacle and a threat, thus reinforcing the idea of the border as a demarcation with an "inside" and an "outside" (Herzog; Sohn, "The Co-mingling of Bordering Dynamics" 7).

In 2002 and 2003, documentary film-maker Phillip Rodriguez produced Mixed Feelings: San Diego/Tijuana and Los Angeles Now. The documentaries were developed within the newly founded City Projects, "a production company whose films and educational programs challenge ideas about race and diversity in America". ${ }^{1}$ In both documentaries, Rodriguez - a Southern Californian with Chicano roots, whose maternal family farmed on the San Diego/Tijuana border - foregrounds the urban configuration of border towns. Whereas Mixed Feelings questions the changing cityscape of two neighboring cities, which are often presented as each other's opposite, Los Angeles Now portrays ethnographic shifts typical of migration flows that, in their turn, are linked to the aforementioned re-bordering process. We argue that Rodriguez, while claiming to represent multilayered and connected worlds, actually urges his audience to consider border towns from a mainly northern perspective. In the present analysis of the socio-spatial paradigm that is being promoted in the two

\footnotetext{
${ }^{1}$ Statement drawn from Philip Rodriguez' website (https://www.philliprodriguez. co/about). Short clips of both documentaries are available on YouTube: see https://www.youtube.com/watch?v=faZ0APrP9-o and https://www.youtube. com/watch? $\mathrm{v}=$ faZ0APrP9-o.
}

Cad. Trad., Florianópolis, v. 40, $\mathbf{n}^{0}$ esp., p. 157-171, jan./jul. sem. 1. 2020. 159 
documentaries, we will pay close attention to multimodal strategies and other discursive practices, as well as to the dominant use of English language and the somehow biased focus on the social actors involved in the documentaries on the border zone.

\section{San Diego-Tijuana, "two extremely different neighbors"2}

In Why Walls Won't Work, Michael Dear terms cities like Tijuana and San Diego "binational 'twin cities", that is, cities with identities sufficiently distinct to earn them the name of "third nation", located in the space between the US and Mexico (xi). This "third nation", according to Dear, functions as a membrane that unites the two nations. Other scholars have focused on patterns of connectivity linking cities across the border (Herzog, "USAMexico Border Cities"), or they have defined the US-Mexican border as a highly permeable membrane (House). Still others have, instead, explored the social and economic interaction between cities in the border region. In Mixed Feelings, Rodriguez compiles fragments of interviews with eight social actors: four from each side of the border. In San Diego, he interviewed four architectscholars, among whom the internationally acclaimed urbanist Teddy Cruz, whereas in Tijuana, the documentary maker spoke to three architects and the electronic music composer Ramón Amor Amezcua Sánchez, better known as Bostich.

In their comments on the evolution of the two border towns, all the interviewees seem to subscribe to the dual nature of San Diego-Tijuana, epitomized by Bostich's following statement: "The beautiful part of Tijuana is San Diego" (15:18). In the documentary, San Diego is described as a green city; Tijuana, by contrast, is called a dusty, dark town dominated by the gray of its asphalt. In reality, both cities should actually benefit from the same ecosystem - in a panoramic shot with a bird's-eye view, a blue demarcation line enhances the chromatic contrast between the two

${ }^{2}$ This quotation is drawn from the documentary's DVD cover.

Cad. Trad., Florianópolis, v. 40, $\mathbf{n}^{0}$ esp., p. 157-171, jan./jul. sem. 1. 2020. 160 
cities. San Diego is also an orderly, rationally urbanized city, full of regulations; in order to stress its regulatory character, passages from these regulations roll over the screen in big black letters while one of the interviewees speaks. In the eyes of several interviewees, this turns San Diego into a sterile city, whereas Tijuana embraces the chaos the US has wiped out, and is therefore lively, creative, and even organic - characteristics to which we will return.

The lively nature of Tijuana is evoked when the Tijuana-based architects observe that the newest real estate projects copy the socalled picturesque, but equally soulless, constructions of projects on the other side of the border; according to their northern colleagues, the latter will only lead to solitude, alienation, boredom, and violence. Rodriguez' photography reinforces the degree to which these real estate projects are mere simulacra: the identical houses are filmed as if they were tombs in a cemetery. At the end of the last century, though, the recycling of these architectural styles was often perceived as having a double-positive outcome, as stated by Lawrence Herzog:

First is the revival of various styles of architecture such as Mission, Spanish Colonial, and so forth; red tile roofs and adobe-like stucco walls are common evidence of Mexican influence. But even more significant may be the landscape created by Mexican migrants in their barrios; here we find ornate fences and religious yardscapes, colorful murals and graffiti, decorated storefronts and elaborate street vendor marketing props-a rich array of imagery to incorporate into the design of transfrontier border cities in the next century. ("The Transfrontier Metropolis")

However, Rodriguez' dystopian view, which seeps into the metadiscourse of all the architects in the documentary, is nuanced by one of the interviewees: the Guatemala-born Teddy Cruz, who does see some signs of creativity within these unified, "prototype" housing projects, in the sense that citizens express 
agency by reappropriating a given space. ${ }^{3}$ Additionally, Rodriguez as a director tends to celebrate Tijuana's creativity through his photography of the city's emergency architecture, which evolved from an ephemeral to a permanent type of housing, mainly in the peripheral shanty towns. In the documentary, the audience is confronted with houses made of rubber tires, palettes, garage doors, and other recycled materials, often coming from demolished housing projects in the US.

Strikingly, the complex history of the emergency architecture remains unspoken on the verbal level. The Tijuana slums are in fact just shown, often from above or from a certain distance, and always from an external viewpoint; there isn't any low-educated counterpart to Rodriguez' highly acculturated voices to recount the lives from within the shabby barracks. Despite the fact that this type of architecture and problematic settlements have been discussed extensively in literature (e.g., Vicky Funari and Sergio De La Torre's Maquilapolis. City of Factories), Rodriguez leaves it to the viewers' trained or curious eyes to retrace the (transborder) history of the houses and the shanty towns they form. An example of this "silent" photography is the sequence in which the camera zooms out from an unrecognizable detail, which turns out to be a patchwork statue. Its right arm visibly taped to it, the statue seems to be purposely put in place as if it arises in the middle of a square, whilst surrounded by destitute housing. This carefully construed and staged sequence, which ends surprisingly with an establishing shot, might be read as an ironic critique of the lack of decent public space. However, Rodriguez' exclusively visual and socially distant approach primarily comes across as an exaltation of poverty that reinstates the US-Mexican border as a fixed line, firmly located in space.

\footnotetext{
${ }^{3}$ In more recent years, the architect-urbanist, also the first to appear in this short documentary, has become internationally renowned for his projects - conducted in collaboration with political theorist Fonna Forman - on cross-border urban intervention. Among other things, these projects improved life and infrastructure in the shanty towns located along the borders (http://estudioteddycruz.com/).
}

Cad. Trad., Florianópolis, v. 40, $\mathrm{n}^{0}$ esp., p. 157-171, jan./jul. sem. 1. 2020. 162 
Clearly, Mixed feelings is a synchronic depiction, which does not want to delve into the border towns' past, or into their historical problems, even if the latter could shed light on some of the characteristics examined in Border Studies (Herzog, "Crossnational Urban Structure" and "The Transfrontier Metropolis"): for example, San Diego's decentralized and car-based urban structure, and its growth patterns, similar to those in Tijuana prior to Mexico's independence. The same applies to the city's traces of commodified, (post)colonial architecture and art, which the camera records in moving shots; yet, any meta-comment or architectural-imagological perspective is lacking. Rodriguez and editor Claudio Rocha, instead, seem to want to create a visually compelling montage by means of the split-screen technique. By splitting up the camera frame, Rodriguez and Rocha project two or more images on separate parts of the screen, which are almost immediately replaced by other images. When there is a transition between images, a short superimposition of blurring images renders the static shots fluid.

In other shots, Rodriguez adds a different background to accompany the subject in the front, while often tilting the camera to the Dutch angle; this particular camera inclination causes a sense of unease or disorientation, but also magnifies the dimensions of the filmed space thanks to the so-called participative view. The use of these multiple angles is exemplary of the director's strategically construed type of messaging, which is corroborated by the equally complex nature of the soundtrack. This soundtrack has both an extra- and intradiegetic city soundscape, to which the director adds Nortec, a form of electronic dance music developed in Tijuana - the interviewee Bostich is one of its main exponents. An original mix that combines traditional forms of Mexican music with dance beats, Nortec initially represented a counter-discourse "to [the] ethnic and economic subordination to the socially dominant Anglo Americans" (Dell'Agnese 180). The audience, if unfamiliar with the political roots of this music genre, might not grasp the underlying ideological meaning of the Nortec soundtrack, but it will nevertheless interpret it as a carrier of the narrative's visual upbeat rhythm. Notable, 
furthermore, is the use of Manu Chao's iconic song "Welcome to Tijuana", which accompanies a sequence featuring one of several prototype architectural projects of Tijuana: Villa Fontana, a monotonous and boring dormitory town. While highlighting and critically addressing some of the darker and libertine sides of Tijuana, the mestiza song has been received as a "marker of 'resistance' against the forces of globalization" (Dell'Agnese 183). The question remains, however, to what extent Manu Chao's message of political awareness and activism may be perceived by a mainstream audience to whom no further explanation is given.

\section{Los Angeles 2.0}

In Los Angeles Now, Rodriguez takes his aestheticizing approach to another level, as announced on the DVD cover:

The film uses creative visuals and computer-generated imagery to evoke the city's vast array of moods and rhythms. And it abandons the polite P.C. language of 90s multiculturalism to explore challenging questions and provocative points of view. ${ }^{4}$

In this second documentary, the verbal mode is overtly subordinate to a more captivating, visual one: the voice-over, the scraps of interviews and the poem by Charles Bukowsky that run across the screen are accompanied by more elaborate accelerations and visual effects, such as panoramic views, multiple and spinning shots and zooms, combined with a computer-generated imagery that creates three-dimensional effects based on the superimposition of two-dimensional images (e.g., a cut-out figure or object moving in front of an equally moving background image).

${ }^{4}$ This quotation is drawn from the documentary's DVD cover.

Cad. Trad., Florianópolis, v. 40, n $^{0}$ esp., p. 157-171, jan./jul. sem. 1. 2020. 164 
The aforementioned visual effects add to the techniques already used by Rodriguez in Mixed Feelings: overlapping and blurring images, animated maps, split-screen sequences, and an experimental soundtrack. In a certain sense, Rodriguez forsakes a solid narrative content, privileging a particularly subjective and rhetorically unconvincing tone. At best, Rodriguez' production, interspersed with aesthetic aids and computer-generated images, blurs visual boundaries, thus conveying a sense of dynamics that reflects the urban changes evoked by the social actors, while lacking a truly political dimension. In his interpretation of the ethnic shift in Los Angeles, described as "now the most multicultural city in the history of the world", 5 Rodriguez only vaguely alludes to urban geography theories as formulated by the authoritative Edward Soja, for instance; he does, however, rightfully point out that LA (Los Angeles) - despite its many layers and areas - lacks a concentric logic, which seems to prevent people from meeting one another. In the wake of other documentary film-makers such as Luis Mancha, Rodriguez addresses the isolation of LA's inhabitants, for example when Mexican-American actress and producer Salma Hayek is shown quoting Bukowski's poem "Like a polluted river flowing"; according to Bukowski, the highway(s) is (are) the only space(s) where people meet and collide, a quote cited also by the scholar-writer Alejandro Morales in Inner Borderlines (Lanslots; Van Hecke).

In Los Angeles Now, Rodriguez also tries - with the help of his interviewees - to define LA's specificity. The identity of the Californian city is consistently described in terms of a duality: both within the city itself, and within the State of California and the US. Rodriguez' analysis of LA is construed mainly around eight "dualities". For instance, as far as the urban configuration is concerned, LA has both a high and low architecture, without any typical style. It was originally conceived as a garden city, which explains the abundance of gardens in a city built on 'desert' ground, as evidenced in a horizontal split-screen. Through this same split

${ }^{5}$ This quotation, too, is drawn from the documentary's DVD cover.

Cad. Trad., Florianópolis, v. 40, n $^{0}$ esp., p. 157-171, jan./jul. sem. 1. 2020. 165 
image, Rodriguez shows how, below the surface, LA is seismically unstable. Directly related to this specific property of LA's soil is - in the director's view - its ephemeral nature. The city not only rejects, or removes, its desert substrates and shared geocultural history with Mexico, but it is also made of diasporic fluidity and uprootedness: all subjects and objects appear to be movable.

According to the interviewees, LA defines itself twice in terms of East versus West; it not only praises itself for its dynamic character, as opposed to the static Midwest, but it is - in itself - divided in a western and an eastern side, which oppose the rich and the poor. Moreover, despite its cruel nature and history of violence and generational riots, LA is applauded for its resilience, which keeps bringing new inhabitants to the city; their dreams for a better life, however, are often broken. Rodriguez portrays LA as a real but fundamentally inauthentic space, as a land of illusion and brief fame, whose inhabitants seem destined to chase dreams based on chimeric simulacra of worldly role models and hollowed-out iconographies.

Another striking feature of Mixed Feelings and Los Angeles Now is the dominant use of the English language. Whereas both documentaries intend to highlight the multicultural character of an area or town that, historically, was predominantly Spanish, Rodriguez' approach towards borders and multiculturalism is clearly monolingual (Gramling). The documentary film-maker and his interviewees almost consistently use English to discuss today's border towns, except for the two female architects in Mixed Feelings - who comment on the implementation of prototype architecture in Tijuana - and the Honduran radio personality Renán Almendárez Coello in Los Angeles Now. The latter is the only social actor to ostentatiously address the audience in Spanish; this occurs when he explains how he was asked why he wouldn't cross the border so that the "gringos" could listen to him, to which he replied that the others should cross over and come and listen to him. This ensures that his subtitled Spanish voice stands firmly behind the border, while inadvertently raising the issue of the interviewer's implicit monolingualism. In this way, Rodriguez' documentaries conform to already existing models 
of documentaries on the Mexican-American border area, which are largely in English if produced in the United States. Claiming that communication should be bi-directional, Almendárez Coello becomes the exponent of the Latino community, and language an eye-catching identity marker. Other ethnic communities, however, aren't given a spokesperson and remain confined to the visual mode of Rodriguez' documentary narrative.

Furthermore, the social actors who demonstrate how complex it is to unravel LA's essence are - paradoxically - all accomplished and well-known public figures (we counted more than 20), whose identity and affiliation can be explicated in short captions: scholars (Kevin Starr), writers (Wanda Coleman), performers (e.g., Harry Gamboa Jr. and Mark Bradford), radio producers, coaches, policymakers, businessmen, and philanthropists. Those who represent LA's poorest inhabitants, by contrast, remain anonymous and aren't given the opportunity to speak up, while it is precisely their discourse that would have complemented the verbal depiction made by the interviewees. In Los Angeles Now, the West is therefore allowed to speak about the East, while the latter is muted and only "shot" through the director's eye. As in Mixed Feelings, it is the cultural elite that voices the social differences between, for instance, the western and eastern side of the city, thus internalizing the US-Mexican border within the limits of a city.

At the same time, though, Rodriguez' synchronic portrayal seems to express the hope that LA's multilingualism and multilayeredness will enable new generations to infringe the dominant Anglo narrative, as ambiguous as that may sound within a predominantly English discourse. The strength of Rodriguez' narrative probably lies in its (audio)visual dimension, which opens "remote" borders and borderlands to a vast, mainstream audience (Staudt 465). This is why it is difficult to give a straightforward answer to the question whether Rodriguez' rendition of LA reproduces, or rather undermines, "dominant hegemonic narratives of the borderlands" (Staudt 465). While appealing to a wide and mainstream audience, Mixed Feelings and Los Angeles Now - albeit conceived as counter-discourses - 
refrain from addressing the complexity and the "shifts in spatial and temporal scales [that] are needed to perceive the border in its multiple forms, functions and implantations" (Amilhat, Giraut 2).

\section{Untold border stories?}

Both documentaries look at cities in quite a detached manner and represent them as divided spaces, each with their own residents, instead of foregrounding the "border struggles" that migrants face once they reached the other side of the border, that is, the whole range of "everyday practices by which migrants continually come to terms with the pervasive effects of the border, subtracting themselves from them or negotiating them through the construction of networks and transnational social spaces" (Mezzadra, Neilson 13). By focusing on the very figure of the migrant, the concept of "border struggles" opens up to the conflicts and tensions experienced along the border; these, in turn, give rise to new types of political subjects often operating outside the logic of citizenship. The latter are not given any space by Rodriguez, who limits himself to showing housing and emergency constructions from a safe distance, framing and aestheticizing them so as to exalt the poverty and disparity that hide behind their sloppy fronts. Only at the end of Los Angeles Now some of the interviewees suggest that they are waiting for the city to speak up, and that perhaps the time has come to listen to more stories. These stories, however, remain untold in Rodriguez' work.

Since the act of disentangling "border(ities)" - that is, the diversification of the border and its characteristics (Amilhat Szary; Giraut) - on the screen regards our relationship to both spatiality and history, we need other and more diverse discourses in order to unwrite old narratives, as the voice-over in Los Angeles Now states (2:43), and also to cultivate a "willingness to listen multilingually and $[\ldots]$ to become linguistically altered" (Gramling 215). In this respect, both documentaries miss the opportunity to truly enrich the larger socio-cultural polysystem, considered in terms of a 
transmission of knowledge, culture, and affects relating to the lives lived along both national and inner borderlines. Scholars, in turn, should continue to interrogate whether borders are accurately represented in cultural products, and to what extent those renditions reproduce or, by contrast, undermine dominant hegemonic narratives of borderlands, which have long been portrayed as "wild, chaotic, sexualized, and violent places" (Staudt 465-466). In this sense, further investigations into the role of these and other documentary films - such as Brian Kaufman's The Wall and Joerg Steineck's Welcome to Tijuana - as a medium of culture transfer, as well as comparisons among them, may contribute to further frame the debate on the return of linguistic hegemony.

\section{References}

Amilhat Szary, Anne-Laure; Giraut, Frédéric. (Eds.). Borderities and the politics of contemporary mobile borders. London: Palgrave Macmillan, 2015.

Cruz,Teddy ; Forman,Fonna . Avaible to: http://estudioteddycruz.com/. Access: 04 February 2020.

Dear, Michael. Why Walls Won't Work. Repairing the U.S.-Mexico Divide. Oxford University Press, 2015.

Dell'Agnese, Elena. “'Welcome to Tijuana': Popular Music on the US-Mexico Border”. Geopolitics. vol. 20, n ${ }^{0} .1$, (2015): 171-192. Avaible to: https://doiorg.kuleuven.ezproxy.kuleuven.be/10.1080/14650045.2014.979914. Access in: $12 / 12 / 2019$.

Funari, Vicky; De La Torre, Sergio. Maquilapolis. City of Factories. San Francisco: Independent Television Service, 2006.

Cad. Trad., Florianópolis, v. 40, ${ }^{0}$ esp., p. 157-171, jan./jul. sem. 1. 2020.169 
Gramling, David. The Invention of Monolingualism. Sydney: Bloomsbury Academic, 2016.

Herzog, Lawrence A. "Cross-national Urban Structure in the Era of Global Cities: The US-Mexico Transfrontier Metropolis”. Urban Studies. vol. 28, ${ }^{\circ}$. 4, (1991): 519-533.

Herzog, Lawrence A. "USA-Mexico Border Cities: a Clash of Two Cultures". Habitat International. vol. 15, $\mathrm{n}^{\circ}$. 1-2, (1991): 261-273.

Herzog, Lawrence A. "The Transfrontier Metropolis". Harvard Design Magazine. $\mathrm{n}^{0} .1$, 1997. Avaible to: http://www.harvarddesignmagazine.org/ issues/1/the-transfrontier-metropolis. Access in: 05 February 2020.

Herzog, Lawrence A. "Cross-national Urban Structure in the Era of Global Cities: The US-Mexico Transfrontier Metropolis”. Urban Studies. vol. 28, ${ }^{\circ}$. 4, (1991): 519-533.

Herzog, Lawrence A; Sohn, Christophe. "The Cross-Border Metropolis in a Global Age: A Conceptual Model and Empirical Evidence from the US-Mexico and European Border Regions”. Global Society. vol. 28, n . 4, (2014): 441-461.

Herzog, Lawrence A; Sohn, Christophe. "The Co-mingling of Bordering Dynamics in the San Diego-Tijuana Cross-border Metropolis". LISER Working Papers. ${ }^{\circ}$. 1, (2016): 1-19.

House, John W. Frontier on the Rio Grande. Oxford: Clarendon Press, 1982.

Lanslots, Inge; Van Hecke, An. "Bridging the gaps in Southern California: Multicultural spaces throughout the works of Alejandro Morales". Transnationalism(s), edited by Dagmar Vandebosh and Theo D'haen, Amsterdan: BRILL/RODOPI, 2018, p. 192204.

Los Angeles Now. Directed by Phillip Rodriguez, City Projects, 2004.

Lynch, Kevin; Appleyard, Donald. "Temporary Paradise? A Look at the Special Landscape of the San Diego Region.” Report to the City of San Diego, 1974.

Cad. Trad., Florianópolis, v. 40, $\mathbf{n}^{0}$ esp., p. 157-171, jan./jul. sem. 1. 2020. 170 
Mancha, Luis. Inner Borderlines. Visions of America through the Eyes of Alejandro Morales. Films Media Group, 2014.

Mezzadra, Sandro; Neilson, Brett. Border as Method, or, the Multiplication of Labor. Durham: Duke university press, 2013.

Mixed Feelings: San Diego/Tijuana. Directed by Phillip Rodriguez, City Projects, 2002.

Nichols, Bill. Introduction to Documentary. Indiana: Indiana University Press, 2001.

Simon, Sherry. "The City in Translation: Urban Cultures of Central Europe". Target. vol. 24, $\mathrm{n}^{\mathrm{o}} .1,(2012)$ : 126-140.

Soja, Edward W. Postmetropolis: Critical Studies of Cities and Regions. Oxônia: Blackwell, 2000.

Staudt, Kathleen. "The Border, Performed in Films: Produced in both Mexico and the US to "Bring Out the Worst in a Country'". Journal of Borderlands Studies. vol. 29, $\mathrm{n}^{\circ}$. 4, (2014): 465-479.

Rodriguez, Phillip. Avaible to: https://www.philliprodriguez.co/. Access in: 04 February 2020.

The Wall. Directed by Brian Kaufman, USA TODAY Network, 2018.

Welcome to Tijuana. Directed by Joerg Steineck, Journeyman Pictures, 2009.

Recebido em: 28/02/2020

Aceito em: 10/05/2020

Publicado em julho de 2020

Inge Lanslots. E-mail: inge.lanslots@kuleuven.be ORCID: https://orcid. org/0000-0002-9369-4958

Natalie Dupré. E-mail: natalie.dupre@kuleuven.be ORCID: https://orcid. org/0000-0003-4587-0467

Cad. Trad., Florianópolis, v. 40, $\mathrm{n}^{0}$ esp., p. 157-171, jan./jul. sem. 1. 2020. 171 